\title{
Small Sawmills Persevere While the Majors Close: Evaluating Resilience and Desirable Timber Allocation in British Columbia, Canada
}

\author{
Evelyn W. Pinkerton ${ }^{l}$ and Jordan Benner ${ }^{1}$
}

\begin{abstract}
We compared the resilience to economic shocks—such as the downturn of the U.S. housing market—of commodity sawmills, which tend to be large, and value-added specialty sawmills, which tend to be small or medium in size, that are located in one region of the province of British Columbia, Canada, as measured by their average days in operation over the last decade and during the 2007-2009 recession. Using a combination of qualitative and quantitative measures, we then examined three behavioral characteristics contributing to their different degrees of resilience: flexibility, diversity, and orientation to place. We found that the specialty mills had greater resilience over the decade because they (a) contributed more jobs per volume of wood consumed and produced, (b) had greater flexibility to operate further below their capacity, (c) produced more diverse primary and secondary (value-added) wood products, (d) targeted more diverse markets, and (e) did more log sorting and trading in logs of different species with other specialty mills and with local commodity mills, with whom they acted as a resilient cluster. Although all these activities resulted in more logs flowing toward their highest value use, we found that the specialty mills lacked a secure and adequate timber supply, while the major timber tenures held by the commodity mills went largely unused during the downturn. This finding suggests that, in addition to contributing to resilience within the forest products sector, more access to timber tenure by the specialty mills, or having a greater portion of timber on the open market, would result in more value being produced from publicly owned timber.
\end{abstract}

Key Words: British Columbia, Canada; commodity sawmills; resilience of social-ecological systems; specialty sawmills; timber supply; value-added wood products

\section{INTRODUCTION}

Since the 1880s, the economy of the Canadian province of British Columbia has been closely associated with the forest industry, comprised chiefly of logging and sawmilling. About 94.5\% of British Columbia's forests are owned by the province and the forest industry remains an important component of the economy, particularly in rural areas where an estimated $16 \%$ of employment depends on this resource (Stedman et al. 2004). However, British Columbia's forest sector has been experiencing the most severe downturn in its history (British Columbia Ministry of Forests and Range 2009), resulting in $25 \%$ of medium and large sawmills closing between 2007 and 2009 (British Columbia Ministry of Forests, Lands and Natural Resource Operations 2011). This downturn creates an opportunity to compare the resilience to economic crisis of different types of companies that hold harvesting rights to public timber, and to ask whether those with the greatest resilience are receiving access to timber that is proportional to their contribution to economic and social stability in difficult times.

The importance of this question has been heightened by policy changes, beginning in 2003, which altered the historical social contract between the public and companies given rights to harvest public timberlands. Before 2003, most companies that held cutting rights to public timber were required to do at least primary processing in the province and they required ministerial permission to close and combine local mills into larger regional mills. Although official forest policy statements still reflect this goal of promoting community stability and welfare, and other goals such as maximizing global competitiveness, jobs, and value recovered from timber, de facto policy has differed. Raw log exports, increasingly to China, exceeded $6 \%$ of the allowable annual cut in 2011, leaving some sawmills without a raw log supply (Dumont and Wright 2006). Although some of the larger sawmills are now reopening to send primary production (commodity lumber) to China (which currently receives $33 \%$ of British Columbia's total lumber production while the historically dominant U.S.A. receives only $48 \%$ as of December 2011 (British Columbia Ministry of Forests, Lands and Natural Resource Operations, personal communication), there is no policy in place to enhance opportunities for secondary value-added timber production. Such production is normally considered highly desirable because it recovers higher value from public resources and has a chance of competing effectively on diverse global markets (Poyry 2001) and produces more jobs (Wilson et al. 2001). British Columbia had the smallest ratio of value added wood to total wood exports of any province in Canada in 2002 (Schrier 2003). Woodbridge (2009) predicts that "as a result of the manufacturing sector's inability to add value and wealth within the manufacturing process, the industry will fall into sharp decline, with further losses of jobs and income." There is considerable agreement that significantly more value could be produced from British Columbia's timber products which 
target the large value-added market, but so far government's economic strategy is market, but not product, diversification, leaving British Columbia still dependent on the United States', and now also China's lower-value commodity markets (Parfitt 2011).

An examination of the mill closures of 2007-2009, which were not evenly spread across tenure and sawmill types, raises important questions regarding the best allocation of timber access for achieving government's stated policy goals. The closure of many sawmills producing commodity lumber and owned by holders of large tenures furnishing raw supply, while many specialty sawmills producing valued-added wood remained in operation-even as they struggled for timber supply, raises questions about differences in these large and small sawmills' resilience to economic shocks. What are the key differences between these specialty sawmills and the commodity sawmills which can explain their different degrees of resilience? What do these differences tell us about how access to public timber should be balanced? We compare the behavior and characteristics of specialty mills and commodity mills in light of what these characteristics contribute to (or detract from) their resilience, and thus their ability to maintain operations during economic downturns. We ask specifically: to what extent do specialty or commodity mills display these features of flexibility, diversity, and security, which the literature suggests are relevant to their resilience? Although the commodity mills used mass production strategies and were thus larger than the specialty mills, we focus here on the strategy of the mill (speciality vs. commodity) rather than the size.

\section{THEORETICAL APPROACH}

This examination of the effect of enterprise size and function on forest products sectors is highly relevant given the relatively small amount of secure forest tenure available to smaller operators in British Columbia, and the worldwide literature on the value and resilience of small mills. For example, Lee and Eckert (2002) note greater stability and persistence of employment in small lumber mills over three decades compared to large lumber mills in the Pacific Northwest, Japan, and the U.S.A. in general, even with timber supply in decline. Although they do not inform us whether the small mills in this study represent specialty mills, it is likely that these smaller mills tend to focus on specialty products as they would have difficulty competing in mass production of commodity lumber.

Other studies find that there are more opportunities for growth in the value-added sector (Kozak 2007, Nelson et al. 2009), which is concentrated in smaller mills. This literature suggests that there are differences in the strategies used by value-added mills with small amounts of tenure (rights to cut on public forest lands) and those used by commodity mills with much larger tenures, which affect their resilience and capacity to add value. Obviously, both mill types are needed, because any stand of timber contains a mixture of high quality and lower quality wood, and British Columbia's current forest practices dictate "cutting the profile" or harvesting from all species so that forest structure and function are not impaired. Our question here, in addition to the resilience question, is whether the optimum amount of higher quality timber is flowing to more valued-added uses.

We use the concept of resilience to refer to the ability of a system to absorb perturbations and retain the same relationships, structures, and functions without collapsing into a qualitatively different state (Holling 1973, Folke et al. 2004). The literature on resilience of social-ecological systems (Berkes and Folke 1998) identifies characteristics of systems that make them resilient to change and shocks, i.e., they are able to maintain the system characteristics necessary to carry out their critical activities and perform their key functions. Here we use a simple primary measure of resilience: average days in operation over a decade, and also during a multiyear economic downturn. In other words, which mills are best able to maintain a substantial degree of operational function over the long term, and especially during economic crisis? It should be noted that in British Columbia's sawmilling industry, the most recent crisis is the third in the last three decades, as discussed below.

Then we analyze what characteristics of the operation of the specialty and commodity mills are likely to have contributed to their resilience, or ability/inability to stay in operation. The characteristics we examine are consistent with some of the general features of forest tenure systems which are found to be needed for the $21^{\text {st }}$ century: flexibility, diversity, security, transparency, social legitimacy, timber pricing for efficiency, stewardship, and low regulatory costs (Haley and Nelson 2007). Here we address only the first three featuresflexibility, diversity, security-because they are the main contributors to resilience (explained below).

In resilience theory as applied to systems, flexibility contributes to resilience by allowing a system to adaptively respond to uncertainty and change. In resource management many governance models have attempted to stabilize components of social-ecological systems through command and control policies, ultimately creating a less resilient system that is more vulnerable to collapse (Holling and Meffe 1996). A variety of scholars therefore argue that a shift is needed towards more flexible forms of management that are more adaptable and responsive (Berkes and Folke 1998, Dietz et al. 2003). Flexibility has also been applied to the strategies of individual sawmills and types of sawmills which already had adapted to or were sometimes forced to adapt to market changes by moving to "flexible specialization" (Barnes and Hayter 1992). We use the concept of flexibility in this sense. 
The role of diversity in contributing to system resilience has been a focus of substantial research on ecosystems (Tillman et al. 1997, Folke et al. 2004). Greater response diversity will increase the likelihood that a system can reorganize after disturbances, and maintain essential functions and structures (Folke et al. 2004). The association between resilience and diversity also extends to the scholarship about social systems, where resilience is associated with economies that are diversified among resources and resource uses (Ashton and Pickens 1995, Garmenstani et al. 2006, Schluter and PahlWostl 2007). Similarly, industrial sectors exhibiting greater functional richness distributed over a range of size classes confer the greatest resilience, including lower employment volatility (Garmenstani et al. 2006). We apply the concept of diversity to types of sawmills and also to the cluster formed by the trading of these sawmills among themselves.

Security is here defined as the "orientation to place" which is particularly exemplified in long-term, owner-operated mills. British Columbia's forest policy parlance normally reserves this term for security of timber supply but, as discussed below, secure timber supply for larger mills does not necessarily keep them in operation. In their paper about employment in the forest industry, Lee and Eckert (2001:79) assume

that large establishments are frequently owned by corporations sensitive to short-term shifts in interest rates and alternative rates of return on investment, whereas [small] private owners are primarily concerned with persistence through difficult times ... . Owners of large establishments, generally corporations responsible to stockholders, must generate a competitive profit to stay in business. When the profitmargin declines, periodic short-term decisions to lay off a shift, close a mill, or terminate logging operations may be reflected in the relative instability of large establishment employment. For the smaller operations owning a single establishment, firm and establishment survival are identical, while for large corporations owning many establishments, the firm and its establishments can be somewhat independent.

In addition to these economic features of orientation to place, our interviews revealed that the survival of an owner-operated small sawmill carried features of loyalty to community and employees, identity, and meaning. That is, owners of small sawmills were likely to stay in operation for reasons going well beyond purely economic ones, reasons such as a desire to stay in a home place and contribute to its well-being. Our paper therefore asks: to what extent do specialty or commodity mills display these features of flexibility, diversity, and security, which appear to be relevant to their resilience? Below we examine all these characteristics as they are manifest in the two types of sawmills.

\section{METHODS}

As measures of the resilience, and resilience-contributing characteristics of flexibility, diversity, and security, we considered the following:

(a) number of days in operation, especially during economic downturns (our primary measure of resilience),

(b) output in relation to capacity, or how far below its capacity a mill was willing to operate (measure of flexibility and security),

(c) number of jobs per volume of wood consumed and volume of output produced (measure of flexibility and diversity),

(d) number of jobs produced (measure of security),

(e) diversity of primary and secondary (value added) wood products (measure of diversity),

(f) degree of $\log$ sorting in the woods and the trade in logs of different species, especially among specialty mills, which provides mutual support for specializations (measure of flexibility),

(g) number of stable jobs and days of operation in proportion to the amount of tenure held (measure of security).

In addition to these quantitative measures, we also used qualitative measures of most of these variables, as discussed below. We selected these variables based on: (a) stated government policy goals, (b) means of achieving these policy goals identified in the literature and by interviewees, (c) key issues identified by interviewees, and (d) the availability of relevant quantitative and qualitative data.

We focused on the $82,338-\mathrm{km}^{2}$ Columbia-Kootenay portion (formerly the Kootenay Forest Region) of the Southern Interior Forest Region in British Columbia, Canada (Fig. 1), which, although it is not necessarily typical of other regions, nonetheless displays instructive dynamics because of the longevity of small/medium, owner-operated mills that have operated successfully for decades, and even three generations in some cases. In 2009 we observed that they remained open while large mills in the region were closed. We focused on sawmills only, because they comprised $77 \%$ of primary log use in 2006, and are the source of $90 \%$ of the fiber used in pulp mills, in the form of chips and sawdust (British Columbia Ministry of Forests, Lands and Natural Resource Operations 2011). A focus on the British Columbia interior region is appropriate, given that the great majority of logging and sawmilling now occurs there, and because the period of "flexible production" and "flexible specialization" on the coast which moved sawmilling beyond the traditional Fordist model of mass production has now largely passed in that region 
(Young and Matthews 2007). Fordism refers to the simultaneous existence of three conditions: oligopolistic corporations investing large capital in mass production mills, organized labor with stable employment, and government providing social services but charging only low royalties (Barnes and Hayter 1992). The depression of the 1980s caused the move from Fordism to flexible specialization on the coast (Barnes and Hayter 1992) while the Asian economic crisis of 1997 largely ended it (Hoberg 2001). In the interior of the province, the traditional Fordist model has been only somewhat altered by the large mills (Barnes and Hayter 1992, Hayter and Barnes 1997), and it is the small mills which have pursued flexible specialization consistently, as discussed below.

Fig. 1. The Columbia-Kootenay portion of the Southern Interior Forest Region. Formerly this area was the Kootenay Forest Region.

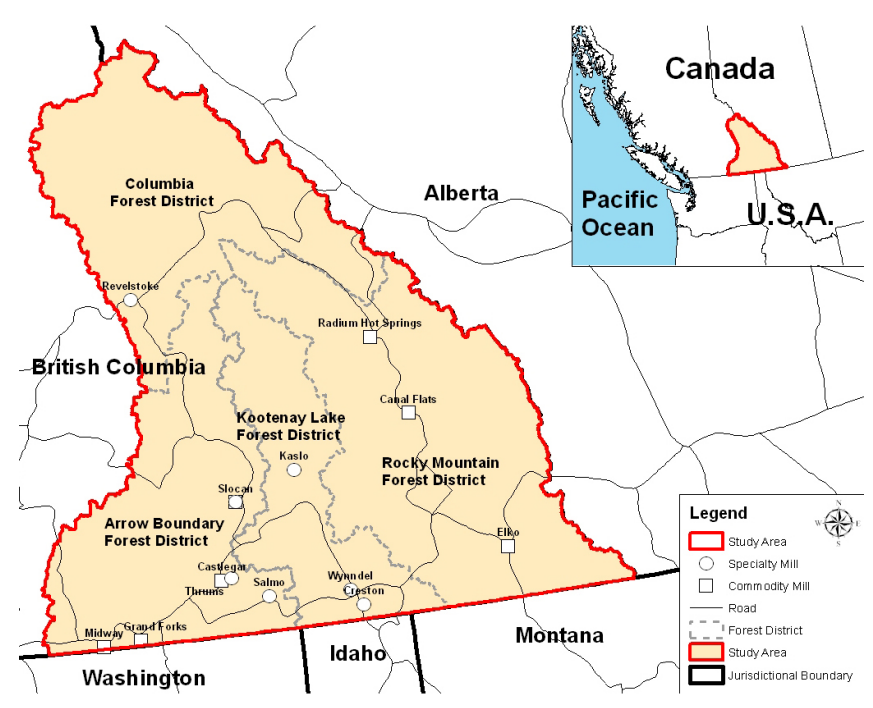

All the mills in our study are considered primary manufacturers. But because they use logs as inputs into production, the specialty mills do secondary manufacturing as well, such as flooring, siding, decking, and laminated stock. Additionally, specialty mills direct the majority of their primary manufacturing capacity towards niche forest products not destined for global commodity markets. We focus on the decade 2000-2009, on five major sawmill owners (called "the majors") who hold tenure in the Columbia-Kootenay region and operate commodity sawmills somewhere in the province whose capacity is 84 to 240 million board feet (MMFBM) $\left(198,218\right.$ to $\left.566,337 \mathrm{~m}^{3}\right)$ and five to eight specialty sawmills operating at various times during that decade whose capacity is 41 to $115 \mathrm{MMFBM}\left(96,750\right.$ to $\left.271,370 \mathrm{~m}^{3}\right)$, who lease and log some forest timberlands, and who have fewer than 250 employees. Table 1 shows the capacity of these mills, revealing that there is some overlap in size between the mill types. What distinguishes them in this analysis is their production strategy more than their size. We exclude mills with a capacity of less than $40 \operatorname{MMFBM}\left(94,390 \mathrm{~m}^{3}\right)$ for simplicity and because this size of mill does not usually have tenure, nor does it participate significantly in the log trading with the other specialty mills.

This sort of regional analysis permits appreciation of the cluster effect (Hayter and Barnes 1997, Poyry 2001, Cortright 2006, DeLong et al. 2007): synergies among mills, both among specialty mills and between them and commodity mills, which could itself contribute to resilience. The clearest unmitigated benefit is exemplified by the trading relationship between specialty mill Porcupine (Porcupine Wood Products Ltd.) and commodity mill Interfor (International Forest Products Limited); Interfor does not produce cedar products, and sells its cedar logs to Porcupine. As a specialty mill whose sole focus is on cedar products, Porcupine sells other species it logs to other mills. The specialty mills want the commodity mills to be in operation so that they can sell their lower value wood to them and also buy higher quality wood from them.

Thirty-six semistructured interviews were conducted in all. In-person interviews occurred with five specialty mill managers or owners and/or staff in summer 2009, as well as with six very small mills not in our sample, by a team which usually included the authors and three other graduate students. These interviews were conducted during a 10-week field season in the British Columbia interior to study five community forests and to compare their forest practices to those of adjacent large-scale tenures. Many community forest board members, managers, and loggers suggested interviewees and supplied information about mill operations. The first author remained longer in each community and conducted three additional in-person interviews alone in 2009 with the specialty mill sample, one with a very small mill and 21 more by telephone in 2010 and 2011 when she was unable to travel to the interior. Telephone interviews included an additional specialty mill, current and previous Ministry of Forests and Range (recently renamed Ministry of Forests, Lands, and Natural Resource Operations) personnel in the region and in headquarters in Victoria, millworker trade union representatives, industry observers in the region and elsewhere, regional community forests personnel, and Canadian Forest Service scientists. In-person interviews were audio recorded and transcribed, while telephone interviews were recorded by typing during the interview. We also reviewed academic literature, government documents, and media reports on tenure policy, export policy, value added, and industry history and characteristics, and drew upon our longer acquaintance with the forest industry as a researcher (first author) and participant (second author manages three woodlots). Five of these interviewees reviewed earlier drafts, resulting in more comprehensive analysis. Triangulation 
Table 1. Specialty and commodity sawmill capacity and tenure held in the Columbia-Kootenay Region (British Columbia Ministry of Forests, Lands and Natural Resource Operations 2010).

\begin{tabular}{|c|c|c|c|c|c|c|}
\hline Mill type & Mill owner & $\begin{array}{l}\text { Capacity } \\
\text { and direction of decadal } \\
\text { change } \\
(\mathrm{MMBF})\left(\mathrm{m}^{3}\right)\end{array}$ & $\begin{array}{l}\text { Mill } \\
\text { location }\end{array}$ & $\begin{array}{l}\text { Tenure } \\
\text { held in } \\
\text { Columbia- } \\
\text { Kootenay } \\
\text { region }\end{array}$ & $\begin{array}{l}\text { Allowable } \\
\text { annual cut } \\
\left(\mathrm{m}^{3}\right)\end{array}$ & $\begin{array}{l}\text { Allowable annual } \\
\text { cut total } \\
\left(\mathrm{m}^{3}\right)\end{array}$ \\
\hline Specialty & Downie Timber Ltd. & $113(+)(266,650)$ & Revelstoke & $\begin{array}{l}\text { A17644 } \\
\text { A31102 }\end{array}$ & $\begin{array}{l}51,315 \\
132,152\end{array}$ & 183,467 \\
\hline Specialty & J.H. Huscroft Ltd. & $58(+)(136,865)$ & Erickson & A20213 & 78,644 & 78,644 \\
\hline Specialty & Kalesnikoff Lumber Co. Ltd. & $72(+)(169,901)$ & Thrums & $\begin{array}{l}\text { A20194 } \\
\text { A30172 }\end{array}$ & $\begin{array}{l}34,703 \\
55,247\end{array}$ & 89,950 \\
\hline Specialty & Wynndel Box \& Lumber Co. & $62(+)(146,304)$ & Wynndel & A20214 & 65,461 & 65,461 \\
\hline Specialty & Meadow Creek Cedar Ltd. $\dagger$ & $48 \dagger(-)(113,267)$ & Cooper Creek & A30171 & 96,513 & 96,513 \\
\hline Specialty & Porcupine Wood Products Ltd. & $58(+)(136,865)$ & Salmo & A56529 & 9,500 & 9,500 \\
\hline $\begin{array}{l}\text { Specialty and } \\
\text { commodity }\end{array}$ & $\begin{array}{l}\text { Slocan Forest Products Ltd. / } \\
\text { Canfor (Canadian Forest Products } \\
\text { Inc.) / Springer Creek Forest } \\
\text { Products Ltd. }\end{array}$ & $115(+)(271,370)$ & Slocan & A20192 & 100,000 & 174,100 \\
\hline Commodity & $\begin{array}{l}\text { Pope \& Talbot Inc. / Interfor } \\
\text { (International Forest Products Ltd.) }\end{array}$ & $120(-)(283,168)$ & Grand Forks & $\begin{array}{l}\text { TFL3 } \\
\text { A18969 }\end{array}$ & $\begin{array}{l}74,100 \\
327,621\end{array}$ & 963,621 \\
\hline & & & & $\begin{array}{l}\text { TFL23 } \\
\text { TFL8 }\end{array}$ & $\begin{array}{l}450,000 \\
186,000\end{array}$ & \\
\hline Commodity & $\begin{array}{l}\text { Pope \& Talbot Inc. / Interfor } \\
\text { (International Forest Products } \\
\text { Ltd.) } \dagger\end{array}$ & $240 \dagger(+)(566,337)$ & Castlegar & See above & & \\
\hline Commodity & $\begin{array}{l}\text { Pope \& Talbot Inc. / Interfor } \\
\text { (International Forest Products Ltd.) } \\
\text { / Fox Lumber Sales, Inc. } \dagger\end{array}$ & $144 \dagger(-)(339,802)$ & Midway & $\begin{array}{l}\text { Tenure sold } \\
\text { to Interfor }\end{array}$ & & \\
\hline Commodity & $\begin{array}{l}\text { Canfor (Canadian Forest Products } \\
\text { Inc.) }\end{array}$ & $183(+)(431,832)$ & Radium Hot Springs & A30176 & 0 & 221,005 \\
\hline & & & & A18979 & 221,005 & \\
\hline Commodity & $\begin{array}{l}\text { Tembec Industries Inc. (sold to } \\
\text { International Forest Products Ltd. } \\
\text { December 2011) }\end{array}$ & $176(+)(415,314)$ & Canal Flats & A18978 & 220,668 & $1,009,901$ \\
\hline & & & & A19040 & 477,652 & \\
\hline & & & & A20212 & 99,081 & \\
\hline & & & & A81368 & 0 & \\
\hline & & & & A84741 & 15,000 & \\
\hline & & & & A84742 & 17,500 & \\
\hline & & & & TFL14 & 180,000 & \\
\hline Commodity & Tembec Industries Inc. (see above) & $188(+)(443,631)$ & Elko & See above & & \\
\hline Commodity & Tolko Industries Ltd. & $\begin{array}{l}\text { No mill in Columbia- } \\
\text { Kootenay region }\end{array}$ & & A20191 & 47,589 & 47,589 \\
\hline Commodity & Weyerhaeuser Company & $\begin{array}{l}\text { No mill in Columbia- } \\
\text { Kootenay region }\end{array}$ & & A18970 & 25,944 & 25,944 \\
\hline Specialty & Total & $526(1,241,222)$ & \multirow{2}{*}{\multicolumn{3}{|c|}{ Excluding Springer Creek $=\mathbf{5 2 3 , 5 3 5}$}} & 697,635 \\
\hline Commodity & Total & $863(2,036,453)$ & & & & $2,268,060$ \\
\hline \multicolumn{7}{|c|}{$\begin{array}{l}\text { Specialty mill tenure as } \% \text { of total }=24 \% \\
\text { Specialty mill tenure as } \% \text { of total, if Springer Creek excluded }=19 \%\end{array}$} \\
\hline
\end{tabular}

among these various sources to check the reliability and validity of data and interpretation (Yin 2003) allowed us to develop confidence in our analysis.

Analysis was significantly advanced by quantitative data supplied by the British Columbia Ministry of Forests and
Range, some of which had been aggregated based on our commodity and specialty mill categories to avoid distributing proprietary information. Although insightful, such averaging prevented us from performing statistical analyses on any data grouped in this manner. However, for the number of days that mills remained in operation in each year, we had data for 
individual mills and were thus able to conduct statistical analyses. We tested whether the number of days in operation differed significantly between specialty and commodity mills by analysis of variance using the $1 \mathrm{~m}$ function in the statistical package R (R Foundation for Statistical Computing 2009). This analysis was repeated separately for each year, therefore allowing comparisons between the mill types as well as before and during the forest sector downturn. In total, we analyzed data from six mills of each category for a total of twelve mills analyzed in each year.

\section{RESULTS}

Table 2 shows the number of days sawmills operated in each year as well as the 10-year average and reveals that in 20002009 specialty mills operated an average of 225 days a year while the commodity mills operated an average of 196 days/ year. The commodity mill average is even lower (188 days) if the Rocky Mountain Forest District is excluded, because it is in different terrain and does not contain specialty mills fitting our definition. Although decadal averages demonstrate longterm trends, such numbers mask even more dramatic differences between specialty and commodity mills during the economic downturn. For example, between 2000 and 2006, there is little difference in the days in operation between the two mill categories, but during the height of the market downturn in $2007\left(F_{1,10}=4.31, P<0.065\right), 2008\left(F_{1,10}=5.04\right.$, $P<0.049)$, and $2009\left(F_{1,10}=8.13, P<0.017\right)$, the difference is quite pronounced. In this downturn period specialty mills operated on average 2-3 times more days/year than commodity mills. These differences in days of operation are largely a result of major shutdowns of all commodity mills-most dramatically the Interfor mill in Castlegar which remained shut for more than 2 years (although part of this time was in 2010), and the almost 5-year shutdown of the Pope and Talbot commodity mill in Midway (until late 2011). Both specialty and commodity mills may lay off a shift at various times, but commodity mills are more likely to completely close one mill and keep another running rather than keep both mills running at a reduced rate of production. Such a strategy by commodity mills might allow the corporate owners to survive downturns, but overall it detracts from the resilience of a particular mill, in addition to the effect its closure has on the resilience of the community in which they mill operates-a critical distinction. Community resilience is briefly considered in the Discussion section.

\section{Characteristics that contribute to resilience}

\section{Security/ orientation to place}

The willingness to continue operating during a downturn is an important outcome of stable orientation to place. As one specialty mill manager commented: "If you live in a community, you have a sense of responsibility; it kills you to lay people off, but executives for the majors are just accountants, and don't live in the community." The specialty mills are usually owner-operated and constitute the only mill owned by the operator, while commodity mills are owned by major public corporations owned by stockholders in cities or other countries. Stability is created by the specialty mills because decisions are driven by the welfare of community/ employees in addition to the welfare of the company. Hence they maintain high loyalty of employees to the mill by going to great lengths to keep them employed and often deciding on layoffs democratically. Majors make decisions about number of days or even staying in operation based on shorter-term and different criteria, as discussed below.

Specialty mills may also make a greater effort than do commodity mills to stay open during economic recessions because they are more vulnerable to loss of markets. During poor markets, larger firms with multiple mills can simply supply what commodity market there is from any of their mills, while smaller firms with a single mill may lose critical niche markets if they shut down and are not able to supply those market demands.

\section{Flexibility}

(a) Output in relation to capacity, or how far below its capacity a mill was willing to operate. Tables 3 and 4 compare the specialty mills that operated during this decade to the commodity mills to show that the specialty mills on average operated at $62 \%$ of their capacity, while the majors chose to operate only when they were on average at $91 \%$ of their capacity. This is an important indicator of flexibility, revealing that specialty mills could operate at a much wider range of their capacity than the majors: the fixed costs of the majors' large mills require a very high constant volume of output to make it profitable. Also, specialty mills' willingness to operate so far below their capacity is another indicator of stable orientation to place, because they will accept a greater reduction in profits and still remain in operation. In contrast, the commodity mills tended to completely close particular mills which were operating at less than $91 \%$ of their capacity rather than cut back the production of several mills.

It is notable that the five specialty mills that were the most stable all increased their capacity between 2000 and 2009, as shown in Table 1, indicating that they were investing in technology to increase the value they added. In the same time period, three commodity sawmills increased their capacity while two decreased it. Commodity mills also invest in technology, but it is focused on speeding up throughput, not on making diverse high-end products. Most of the high technology investment by major corporations is in products other than commodity lumber, such as plywood, laminated products, and pulp, but this is a relatively small portion of British Columbia's production, approximately $20 \%$ (British Columbia Ministry of Forests, Lands and Natural Resource Operations 2011). 
Table 2. Days per year of operation, specialty and commodity sawmills in the Columbia-Kootenay Region, 2000 to 2009 (personal communication, Sinclair Tedder, senior economist, Competitiveness and Innovation Branch, British Columbia Ministry of Forests and Range).$\dagger$

\begin{tabular}{|c|c|c|c|c|c|c|c|c|c|c|c|c|c|c|}
\hline \multirow[b]{2}{*}{ Year } & \multicolumn{7}{|c|}{ Specialty mills } & \multicolumn{7}{|c|}{ Commodity mills } \\
\hline & $\begin{array}{l}\text { Downie } \\
\text { Timber }\end{array}$ & $\begin{array}{l}\text { Kalesnikoff } \\
\text { Lumber Co. }\end{array}$ & $\begin{array}{l}\text { Wynndel } \\
\text { Box \& } \\
\text { Lumber } \\
\text { Co. }\end{array}$ & $\begin{array}{l}\mathrm{J} \mathrm{H} \\
\text { Huscroft }\end{array}$ & $\begin{array}{l}\text { Porcupine } \\
\text { Wood } \\
\text { Products }\end{array}$ & $\begin{array}{l}\text { Meadow } \\
\text { Creek Ltd }\end{array}$ & Mean & $\begin{array}{l}\text { Grand } \\
\text { Forks }\end{array}$ & Castlegar & Midway & $\begin{array}{l}\text { Radium } \\
\text { Hot } \\
\text { Springs }\end{array}$ & $\begin{array}{l}\text { Canal } \\
\text { Flats }\end{array}$ & $\begin{array}{l}\text { El- } \\
\text { ko }\end{array}$ & Mean \\
\hline 2000 & 238 & 252 & 240 & 231 & 235 & 249 & 241 & 238 & 238 & 238 & 238 & 251 & $\begin{array}{l}2- \\
51\end{array}$ & 242 \\
\hline 2001 & 235 & 250 & 239 & 229 & 215 & 259 & 238 & 223 & 243 & 223 & 228 & 237 & $\begin{array}{l}2- \\
38\end{array}$ & 232 \\
\hline 2002 & 236 & 248 & 240 & 225 & 207 & 278 & 239 & 250 & 249 & 249 & 244 & 249 & $\begin{array}{l}2- \\
49\end{array}$ & 248 \\
\hline 2003 & 236 & 240 & 240 & 225 & 250 & 243 & 239 & 253 & 251 & 241 & 245 & 208 & $\begin{array}{l}2- \\
33\end{array}$ & 239 \\
\hline 2004 & 250 & 220 & 252 & 240 & 243 & 208 & 236 & 251 & 251 & 251 & 242 & 249 & $\begin{array}{l}2- \\
49\end{array}$ & 249 \\
\hline 2005 & 228 & 225 & 242 & 230 & 192 & 245 & 227 & 247 & 248 & 248 & 246 & 214 & $\begin{array}{l}2- \\
54\end{array}$ & 243 \\
\hline 2006 & 244 & 250 & 185 & (230) & 187 & 245 & 224 & 282 & 251 & 248 & 231 & 211 & $\begin{array}{l}2- \\
50\end{array}$ & 246 \\
\hline 2007 & 234 & 228 & 240 & 239 & 234 & 145 & 220 & 217 & 222 & 0 & 231 & 0 & 0 & 112 \\
\hline 2008 & $(211)$ & 150 & $(240)$ & (208) & (230) & 0 & 193 & 110 & 35 & 0 & 92 & 115 & $\begin{array}{l}1- \\
20\end{array}$ & 79 \\
\hline 2009 & 243 & 247 & 222 & 210 & (231) & 0 & 192 & 61 & 0 & 0 & 92 & 115 & $\begin{array}{l}1- \\
20\end{array}$ & 65 \\
\hline $\begin{array}{l}10 \text {-year } \\
\text { mean, } \\
2000 \text { to } \\
2009 \\
\end{array}$ & 236 & 231 & 234 & 227 & 222 & 163 & 225 & $\begin{array}{l}213 \\
197\end{array}$ & 199 & 170 & 209 & 185 & $\begin{array}{l}1- \\
96\end{array}$ & 196 \\
\hline $\begin{array}{l}\dagger \text { Parent } \\
\text { Forests a } \\
\text { October } \\
\text { Creek Fo } \\
\text { because } \\
\text { Decemb } \\
\text { profitabl } \\
\text { specialty } \\
\text { higher p }\end{array}$ & $\begin{array}{l}\text { heses arou } \\
\text { and Range } \\
24,2009 . \\
\text { orest Prod } \\
\text { it was uni } \\
\text { er 2011). } \\
\text { le. For pur } \\
\text { owner, a } \\
\text { ercentage }\end{array}$ & $\begin{array}{l}\text { nd days of ope } \\
\text { s data. The Ca } \\
\text { Canfor (Canad } \\
\text { acts Inc. in } 200 \\
\text { onized and thu } \\
t \text { was a mill th } \\
\text { ooses of this ca } \\
\text { dd it did not ha } \\
\text { of commodity }\end{array}$ & $\begin{array}{l}\text { ration indic } \\
\text { stlegar mill } \\
\text { lian Forest } \mathrm{F} \\
6 \text {. Springer } \\
\mathrm{s} \text { had higher } \\
\text { at Canadian } \\
\text { alculation, t } \\
\text { ve a long re } \\
\text { lumber than }\end{array}$ & $\begin{array}{l}\text { te self repo } \\
\text { was shut do } \\
\text { roducts Inc } \\
\text { Creek shut } \\
\text { benefit pac } \\
\text { Forest Prod } \\
\text { is mill in S } \\
\text { cord with ei } \\
\text { other speci }\end{array}$ & $\begin{array}{l}\text { rting by mi } \\
\text { wn from } \mathrm{M} \\
\text {.) purchase } \\
\text { down in } 20 \\
\text { kages, acco } \\
\text { lucts had re } \\
\text { locan is exc } \\
\text { ther during } \\
\text { alty mills. }\end{array}$ & $\begin{array}{l}\text { h } 2008 \text { to J } \\
\text { e mill in Sl } \\
\text { ecause of } \\
\text { te to its hu } \\
\text { edly "dum } \\
\text { ed because } \\
\text { s decade. N }\end{array}$ & $\begin{array}{l}\text { ne } 28, \\
\text { can fro } \\
\text { nsuffic } \\
\text { nan res } \\
\text { ed" al } \\
\text { it was } \\
\text { tably, }\end{array}$ & $\begin{array}{l}\text { ailable } \\
\text { 10. The } \\
\text { Slocan } \\
\text { t timbe } \\
\text { rees ma } \\
\text { with p } \\
\text { viable } \\
\text { was the }\end{array}$ & $\begin{array}{l}\text { Jm or differe } \\
\text { Jrand Forks } \\
\text { orest Produc } \\
\text { or the size } n \\
\text { ager (person } \\
\text { t of its tenur } \\
\text { ther when or } \\
\text { rgest special }\end{array}$ & $\begin{array}{l}\text { mill was s } \\
\text { ts Ltd. in } \\
\text { till (origin } \\
\text { al commur } \\
\text { e in the ar } \\
\text { erated by } \\
\text { ty mill in }\end{array}$ & $\begin{array}{l}\text { e British } \\
\text { hut down } \\
2003 \text { and } \\
\text { hally a con } \\
\text { nication, T } \\
\text { ea, becaus } \\
\text { a commo } \\
\text { our sampl }\end{array}$ & $\begin{array}{l}\text { olumbia } \\
\text { from Jan } \\
\text { old it to } \\
\text { modity } \\
\text { om Gilg } \\
\text { it was } \\
\text { lity own } \\
\text { e, and it }\end{array}$ & $\begin{array}{l}\text { luary } \\
\text { Sprin } \\
\text { mill), } \\
\text { an, } \\
\text { less } \\
\text { er or } 1 \\
\text { produ }\end{array}$ & $\begin{array}{l}\text { istry of } \\
19 \text { to } \\
\text { nger } \\
\text {, and } \\
\\
\text { by a } \\
\text { uced a }\end{array}$ \\
\hline
\end{tabular}

(b) Number of jobs per cubic meter of wood consumed and per MMFBM of wood produced by specialty vs. commodity sawmills. Tables 3 and 4 show that specialty mills on average produced more than twice the number of jobs per cubic meter of wood consumed as did commodity mills and produced more than three times the number of jobs per MMFBM of wood produced. Viewed from the perspective of pure volume of production, and from the perspective of a mill owner striving to cut costs, the commodity mills could be seen as more efficient, and desirably so. But this view omits important factors such as the value of the product, which is far higher in secondary manufacturing, which permits it to support more jobs.

Of course the specialty mills are able to get higher value because they are using on average higher quality wood, and the commodity mills are putting lower quality wood to its best use. Unfortunately, this rule of thumb is often not the case, as we were frequently informed by loggers, millworkers, and mill owners. Higher quality logs may not be sorted in the woods to begin with. As one owner of a small mill explained: "The biggest reason that a percentage doesn't get to specialty mills is that everybody is in machines and getting paid so much an hour and it's a pest to take a log somewhere else. Their area is narrower, with small landings, no room to sort. You have to leave one log and it might take a week to get enough for a [special] load."

One of the problems for the logging components of major public companies is that they are considered cost centers, not profit centers, so they have no rationale to log for external demand (Nelson et al. 2009). Once a high value log has arrived at a commodity mill, Nelson, Cohen, and Nikolakis (2009) help explain why those mills are often unwilling to sell their higher value logs to the specialty mills, even if they could obtain more income by doing so. Commodity mill managers 
Table 3. Output/capacity ratio and jobs per unit of input and output for specialty mills, 2000 to 2009 (personal communication, Sinclair Tedder, senior economist, Competitiveness and Innovation Branch, British Columbia Ministry of Forests and Range).

\begin{tabular}{|c|c|c|c|c|c|c|c|c|}
\hline$\overline{\text { Year }}$ & $\begin{array}{r}\text { Mills } \\
\text { (no.) }\end{array}$ & $\begin{array}{c}\text { Capacity } \\
(\text { MMFBM) } \\
\left(\mathrm{m}^{3}\right)\end{array}$ & $\begin{array}{c}\text { Output } \\
(\mathrm{MMFBM}) \\
\left(\mathrm{m}^{3}\right)\end{array}$ & $\begin{array}{l}\text { Input } \\
\left(000 \mathrm{~m}^{3}\right)\end{array}$ & Employment & $\begin{array}{c}\text { Output / } \\
\text { capacity ratio }\end{array}$ & $\begin{array}{c}\text { Jobs/ } \\
\text { MMFBM } \\
\text { (output) }\end{array}$ & $\begin{array}{l}\text { Jobs/000 m }{ }^{3} \\
\text { (input) }\end{array}$ \\
\hline 2009 & 6 & $\begin{array}{c}478 \\
(1,127,954)\end{array}$ & $\begin{array}{c}195 \\
(460,149)\end{array}$ & 927 & 822 & 0.41 & 4.21 & 0.89 \\
\hline 2008 & 6 & $\begin{array}{c}461 \\
(1,087,838)\end{array}$ & $\begin{array}{c}187 \\
(441,271)\end{array}$ & 885 & 713 & 0.41 & 3.81 & 0.81 \\
\hline 2007 & 7 & $\begin{array}{c}468 \\
(1,104,357)\end{array}$ & $\begin{array}{c}282 \\
(665,446)\end{array}$ & 1218 & 770 & 0.60 & 2.73 & 0.63 \\
\hline 2006 & 7 & $\begin{array}{c}524 \\
(1,236,502)\end{array}$ & $\begin{array}{c}316 \\
(745,677)\end{array}$ & 1382 & 1100 & 0.60 & 3.48 & 0.80 \\
\hline 2005 & 7 & $\begin{array}{c}476 \\
(1,123,235)\end{array}$ & $\begin{array}{c}293 \\
(691,403)\end{array}$ & 1307 & 1165 & 0.62 & 3.98 & 0.89 \\
\hline 2004 & 6 & $\begin{array}{c}300 \\
(707,921)\end{array}$ & $\begin{array}{c}226 \\
(533,301)\end{array}$ & 1073 & 975 & 0.75 & 4.31 & 0.91 \\
\hline 2003 & 7 & $\begin{array}{c}266 \\
(627,690)\end{array}$ & $\begin{array}{c}172 \\
(405,875)\end{array}$ & 868 & 985 & 0.65 & 5.72 & 1.14 \\
\hline 2002 & 8 & $\begin{array}{c}321 \\
(757,475)\end{array}$ & $\begin{array}{c}191 \\
(450,710)\end{array}$ & 957 & 848 & 0.59 & 4.45 & 0.89 \\
\hline 2001 & 9 & $\begin{array}{c}312 \\
(736,238)\end{array}$ & $\begin{array}{c}197 \\
(464,868)\end{array}$ & 899 & 806 & 0.63 & 4.10 & 0.90 \\
\hline 2000 & 9 & $\begin{array}{c}317 \\
(748,037)\end{array}$ & $\begin{array}{c}227 \\
(535,660)\end{array}$ & 1104 & 794 & 0.72 & 3.50 & 0.72 \\
\hline Mean & & $\begin{array}{c}383 \\
(903,779)\end{array}$ & $\begin{array}{c}232 \\
(547,459)\end{array}$ & 1077 & 906 & 0.62 & 4.01 & 0.85 \\
\hline
\end{tabular}

are required to have a short-term focus on accounting procedures in their production decisions, using productionbased measures of success (volume vs. economic value of product) and having a short-term focus on cost reduction. The investment rules they must live by require short payback periods, often 30 days, so they are not able to take risks by exceeding the evaluation time period. They have to make production targets, make them fast, and get evaluated on volume and grade recovery. Grade recovery is enhanced by higher value timber, even if it is not the highest use of this timber. Poyry (2001) observes that "in western Canada, primary manufacturers look upon remanufacturers as competitors, rather than customers", by which we understand competitors for the highest value timber. It may also be the case that, for the majors, the cost of extra log handling, site disturbance for greater sorting, and the negative impacts these would have on mill productivity and market value makes it not worth their while economically in many cases. We can see in Lee and Eckert's (2001) dictum quoted above that publicly owned corporations are sensitive to short-term shifts in interest rates and alternative rates of return on investment, and this sensitivity appears to often trump their flexibility in getting the highest value from the timber either for themselves, or for the public owners of the resource. Thus they display what Steven Yaffee (1997:330-333) terms a "preference for shortterm rationality over long-term rationality", as well as a "preference for competition over cooperation", strategies that minimize the energy needed to respond to a situation while maximizing control and predictability but lead to inferior outcomes. Strategies of the specialty mills, in contrast, can be said to exhibit long-term rationality and preference for cooperation over competition in that they allocate all species to their highest value by their own production and by trading with other specialty and commodity mills.

(c) Flexibility of work force. The diversity in production strategy of specialty mills (described below) meant that workers often had to be multiskilled and able to shift to different jobs in the mill, depending on particular demand at any time. As one manager put it, "We are resilient because we can change and adapt. Just like a wild species, we need to adapt and can't rely on just one thing. We jump from market to market as demand changes." This could occur because the specialty mills were not unionized (except for Springer Creek) and operated on personal relations with the manager. As another specialty mill manager put it:

We pay the same wages and have a better pension plan than the union. All our workers would fight fires to protect their mill. We need flexibility here. We pay a guy \$35 an hour plus benefits, I hope he's prepared to be flexible!... But in a union, seniority rules, and I want some 18-20 year old to be an electrician, not 
Table 4. Output/capacity ratio and jobs per unit of input and output for commodity mills, 2000 to 2009 (personal communication, Sinclair Tedder, senior economist, Competitiveness and Innovation Branch, British Columbia Ministry of Forests and Range).

\begin{tabular}{|c|c|c|c|c|c|c|c|c|}
\hline Year & $\begin{array}{r}\text { Mills } \\
\text { (no.) }\end{array}$ & $\begin{array}{c}\text { Capacity } \\
(\mathrm{MMFBM}) \\
\left(\mathrm{m}^{3}\right)\end{array}$ & $\begin{array}{c}\text { Output } \\
\text { (MMFBM) } \\
\left(\mathrm{m}^{3}\right)\end{array}$ & $\begin{array}{c}\text { Input } \\
\left(000 \mathrm{~m}^{3}\right)\end{array}$ & Employment & $\begin{array}{c}\text { Output / } \\
\text { capacity ratio }\end{array}$ & $\begin{array}{c}\text { Jobs/ } \\
\text { MMFBM } \\
\text { (output) }\end{array}$ & $\begin{array}{c}\text { Jobs } / 000 \mathrm{~m}^{3} \\
\text { (input) }\end{array}$ \\
\hline 2009 & 4 & $\begin{array}{c}667 \\
(1,573,945)\end{array}$ & $\begin{array}{c}311 \\
(733,878)\end{array}$ & 1175 & 592 & 0.47 & 1.90 & 0.50 \\
\hline 2008 & 5 & $\begin{array}{c}871 \\
(2,055,331)\end{array}$ & $\begin{array}{c}344 \\
(811,750)\end{array}$ & 1280 & 782 & 0.39 & 2.28 & 0.61 \\
\hline 2007 & 3 & $\begin{array}{c}548 \\
(1,293,135)\end{array}$ & $\begin{array}{c}513 \\
(1,210,545)\end{array}$ & 1825 & 597 & 0.94 & 1.16 & 0.33 \\
\hline 2006 & 6 & $\begin{array}{c}1030 \\
(2,430,529)\end{array}$ & $\begin{array}{c}1081 \\
(2,550,876)\end{array}$ & 3914 & 1159 & 1.05 & 1.07 & 0.30 \\
\hline 2005 & 6 & $\begin{array}{c}1090 \\
(2,572,114)\end{array}$ & $\begin{array}{c}1168 \\
(2,756,173)\end{array}$ & 4045 & 1226 & 1.07 & 1.05 & 0.30 \\
\hline 2004 & 7 & $\begin{array}{c}1205 \\
(2,843,483)\end{array}$ & $\begin{array}{c}1223 \\
(2,885,959)\end{array}$ & 4363 & 1373 & 1.01 & 1.12 & 0.31 \\
\hline 2003 & 7 & $\begin{array}{c}1261 \\
(2,975,629)\end{array}$ & $\begin{array}{c}1071 \\
(2,527,279)\end{array}$ & 3896 & 1285 & 0.85 & 1.20 & 0.33 \\
\hline 2002 & 7 & $\begin{array}{c}1173 \\
(2,767,972)\end{array}$ & $\begin{array}{c}1021 \\
(2,409,291)\end{array}$ & 3951 & 1431 & 0.87 & 1.40 & 0.36 \\
\hline 2001 & 7 & $\begin{array}{c}1086 \\
(2,562,675)\end{array}$ & $\begin{array}{c}1014 \\
(2,392,774)\end{array}$ & 3761 & 1380 & 0.93 & 1.36 & 0.37 \\
\hline 2000 & 7 & $\begin{array}{c}1078 \\
(2,543,797)\end{array}$ & $\begin{array}{c}1053 \\
(2,484,803)\end{array}$ & 3901 & 1370 & 0.98 & 1.30 & 0.35 \\
\hline Mean & & $\begin{array}{c}1038 \\
(2,449,407)\end{array}$ & $\begin{array}{c}943 \\
(2,225,232)\end{array}$ & 3437 & 1178 & 0.91 & 1.33 & 0.36 \\
\hline
\end{tabular}

a 50 year old . . the union they had 20 years ago doesn't fit with our operation.

The forklift operators were all women because this mill manager asserted that only the women treated the finished products with the care that was required to prevent any damage.

However, commodity mill Interfor clashed with the union rules, particularly in the Castlegar mill, and claimed that the inflexibility of union rules contributed to the over 2-year shutdown of that mill. After two years of not working, the seniority of workers is eliminated, and thus managers have more flexibility in assigning tasks (as well as lower wages for lower seniority). We did not collect data on wages and benefits for all workers in all specialty mills, which is an area for future research. We hypothesize that not all specialty mills can afford to pay union wages and benefits to all workers, but that they provide a net benefit when the stability of jobs is compared to the job instability of commodity mill workers.

\section{Diversity}

(a) Number and diversity of primary and secondary (value added) wood products of the specialty mills. Because it is difficult to obtain data on the degree of value added by specialty mills, we did not attempt to measure it except by these indirect methods: specialty products are by definition value-added. The diverse value-added products of the five specialty mills in our sample can be viewed on their elaborate and richly detailed web sites and include: decking, paneling, siding, fencing, flooring, furniture grade blanks, laminating stock, pattern stock paneling, trim and fascia, primer-baked siding, microbeveled flooring, etc. in species such as redcedar, Douglas-fir, western larch, Idaho white pine, lodgepole pine, western hemlock, and Engelmann spruce. These mills also offer lumber that is kiln-dried, planed, and custom cut, and many degrees of secondary manufacturing.

One specialty mill recently purchased a 60-bin sorting station. This diversity of products allows the specialty mills to access a number of specialty markets in Japan, Mexico, U.S.A., and across Canada, and large-scale buyers such as Home Depot. Therefore the 2007 downturn in the U.S. housing market did not affect the specialty mills as it did the majors because both their products and their markets were diverse. Even on the domestic market, they were less affected because people may replace or add a deck or improve flooring, but will not build an entire house.

(b) Log sorting in the woods and trade in logs of different species among specialty mills which supports each others' specializations. Although commodity mills do some degree of sorting by species in the woods, it is nothing close to the six to seven species sorts and four grade sorts that specialty mills do on their own logging operations. They skillfully fall 
and buck in the woods and selectively mill to recover the highest value. After logging the timber profile, they select their own specialty wood and trade other species with other specialty mills and with the commodity producers, when they are operating. (Although the majors may do some degree of trading with one another and with nearby specialty mills for species they do not use, their speed and mass production requirements preclude dedicating much time to this). Two mills specialize in cedar, one in spruce, one in pine, and another in five species. Trading relations are sometimes based on strict contracts, as evidenced by the following comment from one specialty mill operator about another specialty mill: "We have a strong relationship with $\mathrm{X}$ and we use their price for spruce, and get all their cedar. If we want to sell elsewhere, we have to have a really good reason .... and if we send them a log with rot that we haven't bucked out, they will first fine us and then cut us off."

As for the commodity mills, despite the recent increase in lumber sales to China, statements continue to be made that full recovery of the commodity lumber industry will not occur until the U.S. housing market recovers. Even though this is projected to be two or more years away (and maybe much longer), one does not hear statements that the basic strategy should change.

\section{DISCUSSION}

Because forest policy can be seen as concerned with how the resilience of social-ecological systems is affected by enterprise stability, the results presented above should be viewed in the broader context of their effect on communities and regions. Both specialty and commodity mills are needed for a well-functioning system due to the heterogeneous nature of wood quality in any stand of timber, but their performance relative to the resilient characteristics outlined above suggests that commodity mills are inherently more rigid and vulnerable to collapse than specialty mills. Consequently, the communities in which commodity mills are situated are also arguably less stable than those with specialty, locally owned mills; they are more vulnerable to the large layoffs occurring in the "bust" cycles of the early 1980s, the late 1990s, and the most recent one starting in 2007 (Hayter and Barnes 1997, Clapp 1998). This greater vulnerability of communities dependent on commodity mills also translates into greater costs to government for providing additional services in welfare, unemployment insurance, and health care. Such cascading effects on the community are compounded by the scale of many commodity operations, which can drive local economies towards dependence on a single, large enterprise, because the owners use global strategies for the basis of decisions in isolation from local consequences

Given these realities, it is important to consider how government policy on allocation of timber access rights affects the viability of the different mill types, and what the optimal allocation might be. Stennes and Wilson (2008) and Stennes et al. (2005) identify lack of timber supply as a key limiting factor in the success of mills. Given their greater proportional contribution of stable jobs, number of jobs in proportion to public forest harvested and product produced, and number of days in operation, we questioned what access the specialty mills had to timber supply compared to the commodity mills, especially given the policy goals of the British Columbia Ministry of Forests and Range to maximize value, employment, and community stability. The specialty mills in our sample that made submissions to the British Columbia's Working Roundtable on Forestry (British Columbia Ministry of Forests and Range 2009) as well as all our interviewees from these mills, mentioned lack of timber supply as a major issue. Several also pointed to the fact that the commodity mills that were attached to large tenures were shut down while specialty mills continued to operate but struggled to find enough raw supply because their own tenure could supply at most one-third of their mill needs. They found it ironic that the Working Roundtable on Forestry identified "high value, globally competitive, sustainable forest industry" and "strong and healthy communities" as key ingredients, and identified under Priority 4 the importance of "embracing innovation and diversification":

\section{The British Columbia forest industry produces primarily dimension lumber, pulp and some panel and other wood products. These will remain essential elements of the British Columbia forest industry but in future there may be fewer, larger, globally competitive firms producing these products once industry goes through its current rationalization. There are opportunities to manufacture new products from the forest resource and British Columbia can lead the world in new product development. \\ (British Columbia Ministry of Forests and Range 2009:32)}

The specialty mills we have described are good examples of innovation and diversification and new product development. Yet these strategies will not be encouraged if they are starved for timber supply, and if timber cannot even be acquired on the open market if the commodity mills will not sell to them or if the market production is largely shut down when the commodity mills shut down. Specialty mills stated that it was also more difficult to sell their lower value timber when the commodity mills were shut down, and that the lack of competition for this wood during those times also drove the price lower. Even foresters for the majors Dumont and Wright (2006:56), in reviewing British Columbia's log export policy, opined that

many of the independent sawmills can more than hold their own in competing so long as there is an adequate supply of logs available in the open market. In our opinion the real cause for the current 
difficulties in log supply that the independents are concerned about are principally caused, not by the Western [Forest Products Inc.] consolidation, but by the fact that there is currently an inadequate supply of logs in the domestic coast log market for all processors.

Because the timber supply question is so central (in the interior as well as on the coast), we decided to see if the contribution of the specialty mills to days in operation was reflected in their access to timber supply. Table 1 shows the relatively secure access to timber supply of specialty and commodity mills (including some companies with tenure who send their timber to their mills outside the region). Compared to Tables 2, 3, and 4 , it reveals that current tenure allocation is not proportional to operational or employment stability of mills. While specialty mills hold $24 \%$ of tenure directly serving sawmills in the region, they contributed an average of $43 \%$ of the jobs from 2000 to 2009 and $54 \%$ of the jobs from 2007 to 2009 (58\% in 2009). As noted above, specialty mills also contributed an average of 53\% of the day in operation from 2000 to 2009 , and $70 \%$ during the downturn.

We considered whether major companies holding tenure in the region might be sending timber to mills outside the region which had a different pattern than mills in the region. This did not prove to be the case, as the commodity mills outside the region showed the same pattern of shutdowns as the commodity mills in the Columbia-Kootenay region. The majors as multinational forest enterprises could be considered resilient at an international and sometimes provincial enterprise scale (although Barnes and Hayter 2005 point to the disappearance of majors such as MacMillan Bloedel which flourished only until the 1990s), but this scale of resilience occurs at the expense of communities and regions where they hold tenures and mills not in operation during recessions.

Springer Creek, the largest specialty mill which shut down in 2009, cited timber supply as a key contributing factor, because much of its timber was being taken out of production through withdrawals in the Slocan Valley, whereas Canfor (Canadian Forest Products Inc.) from whom the mill was acquired, was reputed to have "dumped" this mill because of a difficult situation. A second factor in the case of Springer Creek was that the mill had a larger commodity lumber component, and was unionized and thus had less flexibility. If Springer Creek is excluded from our statistics on mill categories, specialty mills hold only $19 \%$ of the tenure.

The 1991 provincial Peel Commission on Forest Policy (British Columbia Forest Resources Commission 1991) attempted to address the question of unequal access to tenure by recommending that at least $50 \%$ of the allowable annual cut be accessed through an open bid system, not through longterm tenure allocations. Our interviewees had a different view of the best policy for achieving more equal access. They preferred to see an increase in the diversity of access rights, because the continuing tendency toward concentration of major firms increases the market power to those firms and lessens the capacity of small firms to compete for public timber in a bidding system (Nelson and Niquidet 2009). British Columbia is far from attaining the 50\% recommended situation, and instead ownership is becoming less diverse and more concentrated. As we finalize this manuscript, commodity producer Canadian Forest Products Inc. has just acquired the two Tembec Industries Inc. mills in the Columbia-Kootenay region. The 2003 Forestry Revitalization Act did make 20\% more of the allowable annual cut of public timber available to several types of small tenure holders, including the competitive, open-bid BC Timber Sales program, thereby theoretically making more timber available to specialty mills. However, these mills are still at a disadvantage in competing for these sales because they do not always have the capital resources available in the time frames needed to bid, while larger firms are in a stronger position to bid through other firms. Although the specialty mills have diverse characteristics that help them adapt, they are not helped by the fact that British Columbia's tenure system as a whole has far less than optimal diversity.

\section{CONCLUSIONS}

The results presented above demonstrate that specialty mills in our sample area were more resilient to economic downturns than commodity sawmills, as measured by days in operation. Together the qualitative and quantitative data also suggested that the greater resilience of the specialty mills was a response to higher levels of flexibility, diversity, and orientation to place or security, as measured by: (1) their willingness and ability to operate more flexibly and much further below their capacity, (2) their ability to produce a greater diversity of products targeting more diverse markets, (3) their ability to produce higher value products - as indicated by their ability to support more than twice the jobs per thousand cubic meter consumed and also more than three times the number of jobs per million board feet of wood produced, and (4) their ability to sort many grades of wood in the woods and to flexibly trade among themselves-and to some extent the commodity mills as well, when they were open - and to operate as a cluster which made each mill more effective and resilient than they could be as individual enterprises.

In contrast, the commodity mills' pattern of employment and days of operation over time demonstrated a lack of resilience to shocks. The bankruptcy of Pope \& Talbot Inc. which owned the Interfor mills earlier in the decade; the shutdowns of the commodity mills of Interfor, Canfor, and Tembec; and Canfor's sale of less-profitable mills such as Springer Creek are examples of strategies adapted to ownership patterns at a provincial, national, or global level, but not at a local or regional level. 
But stability at a local level can contribute to stability at larger scales. Perhaps even more important than the number of jobs or days operating is the stability of specialty mills through prosperity and recession. Keeping people employed during recessions is valued by economists because, even if the specialty mills subsidize their employees for periods (stay in operation when just breaking even or even a little less), this is very desirable for the economy because it prevents the drop in economic activity, unemployment, loan defaults, etc. that contribute to economic recession. This contribution in both number of jobs and stability, in addition to the creation of more value from public timber, suggests that more reliable access to timber supply by specialty mills is warranted. The literature and the situation of approaching scarcity of timber and increased competition from Asia suggests that the wave of the future lies in a "value-focused" strategy that does more with less rather than a cost-reduction strategy that does less with more (Kozak and Maness 2005).

Responses to this article can be read online at: http://www.ecologyandsociety.org/issues/responses. $\mathrm{php} / 5515$

\section{Acknowledgments:}

We thank the Social Sciences and Humanities Research Council of Canada for their support of this research through a grant to Evelyn Pinkerton and co-investigators John Welch, Murray Rutherford, Ken Lertzman, Ron Trosper, and Thomas Maness, and we thank the graduate students who participated in the research: Lauren Rethoret, Dave Mealiea, and Ashley Smith. We thank all the respondents who patiently answered our questions over the last three years. We especially thank Sinclair Tedder, Jim Langridge, Ray Travers, Cindy Pearce, and Tom Gilgan for data, helpful advice, and helpful comments on an earlier draft, and Erik Leslie for first making us aware of this situation. Any errors of interpretation or fact are entirely our own.

\section{LITERATURE CITED}

Ashton, P. G., and J. B. Pickens. 1995. Employment diversity and economic performance in small resource-dependent communities near western national forests. Society \& Natural Resources 8(3):231-241. http://dx.doi.org/10.1080/08941929509380917

Barnes, T., and R. Hayter. 1992. "The little town that did": flexible accumulation and community response in Chemainus, British Columbia. Regional Studies 26(7):647-663.

Barnes, T., and R. Hayter. 2005. No "Greek-letter writing": local models of resource economies. Growth and Change 36 (4):453-470. http://dx.doi.org/10.1037/e528652009-001
Berkes, F., and C. Folke, editors. 1998. Linking social and ecological systems: management practices and social mechanisms for building resilience. Cambridge University Press, Cambridge, UK.

British Columbia Forest Resources Commission. 1991. The future of our forests. A.L. (Sandy) Peel, Chairman. Victoria, British Columbia, Canada.

British Columbia Ministry of Forests and Range. 2009. Moving toward a globally competitive, sustainable forest industry. The report on the Working Roundtable on Forestry. Working Roundtable on Forestry, Victoria, B.C., Canada. [online] URL: http://www.for.gov.bc.ca/mof/forestry roundtable/ Moving Toward a Globally Competitive Forest Industry.pdf.

British Columbia Ministry of Forests, Lands and Natural Resource Operation. 2010. Timber tenures-AAC, apportionment and commitments-Timber supply area reports. Victoria, B.C., Canada. http://www.for.gov.bc.ca/ftp/ HTH/external/!publish/web/timber-tenures/apportionment/

British Columbia Ministry of Forests, Lands and Natural Resource Operations. 2011. Major timber processing facilities in British Columbia 2009. Competitiveness and Innovation Branch, Victoria, B.C., Canada. [online] URL: http://www. for.gov.bc.ca/ftp/het/external/!publish/web/mill\%20list/Public\% 20Report\%202009.pdf.

Clapp, A. 1998. The resource cycle in fishing and forestry. Canadian Geographer 42(2):129-144. http://dx.doi.org/10.1111/ j.1541-0064.1998.tb01560.x

Cortright, J. 2006. Making sense of clusters; regional competitiveness and economic development. A discussion paper prepared for the Brookings Institution Metropolitan Policy Program. Brookings Institution, Washington, D.C., USA.

DeLong, D. L., R. A. Kozak, and D. H. Cohen. 2007. Overview of the Canadian value-added wood products sector and the competitive factors that contribute to its success. Canadian Journal of Forest Research 37(11):2211-2226. http://dx.doi. org/10.1139/X07-027

Dietz, T., E. Ostrom, and P. Stern. 2003. The struggle to govern the commons. Science 302:1907-1912. http://dx.doi. org/10.1126/science.1091015

Dumont, B., and D. Wright 2006. Generating more wealth from British Columbia's timber: a review of British Columbia's $\log$ export policies. Victoria, B.C. A report for the British Columbia Minister of Forests and Range. Victoria, B.C., Canada.

Forestry revitalization act. Bill 28-2003. 2003 Legislative Session: 4th Session, 37th Parliament. Government of British Columbia, Canada. 
Folke, C., S. Carpenter, B. Walker, M. Scheffer, T. Elmqvist, L. Gunderson, and C. S. Holling. 2004. Regime shifts, resilience, and biodiversity in ecosystem management. Annual Review of Ecology Evolution and Systematics 35:557-581. http://dx.doi.org/10.1146/annurev.ecolsys.35.021103.105711

Garmestani, A. S., C. R. Allen, J. D. Mittelstaedt, C. A. Stow, and W. A. Ward. 2006. Firm size diversity, functional richness, and resilience. Environment and Development Economics 11:533-551. http://dx.doi.org/10.1017/S1355770X06003081

Haley, D., and H. Nelson 2007. Has the time come to rethink Canada's Crown forest tenure systems? The Forestry Chronicle 83(5):630-641.

Hayter, R. and T. Barnes. 1997. The restructuring of British Columbia's coastal forest sector. BC Studies 113:7-34.

Hoberg, G. 2001. "Don't forget government can do anything": policies toward jobs in the $\mathrm{BC}$ forest sector. Pages 207-231 in B. Cashore, G. Hoberg, M. Howlett, J. Rayner, J. Wilson, editors. In search of sustainability. British Columbia forest policy in the 1990s. University of British Columbia Press, Vancouver, B.C., Canada.

Holling, C. S. 1973. Resilience and stability of ecological systems. Annual Review in Ecology and Systematics 4:1-23. http://dx.doi.org/10.1146/annurev.es.04.110173.000245

Holling, C. S., and G. K. Meffe. 1996. Command and control and the pathology of natural resource management. Conservation Biology 10:328-337. http://dx.doi.org/10.1046/ j.1523-1739.1996.10020328.x

Kozak, R. 2007. Small and medium forest enterprises: instruments of change in the developing world. Rights and Resources Initiative, Washington, D.C., USA.

Kozak, R., and T. Maness. 2005. Towards a value focused forest sector in British Columbia. Issues Brief IB: 05-01. BC Forum on Forest Economics and Policy, Forest Sciences Centre, Vancouver, B.C., Canada.

Lee, R. G., and P. J. Eckert, 2002. Establishment size and employment stability in logging and sawmilling: a comparative analysis. Canadian Journal of Forest Research 32:67-80. http://dx.doi.org/10.1139/x01-146

Nelson, H., D. Cohen, and W. Nikolakis. 2009. Are forest sector firms maximizing the economic returns from their timber? Evidence from British Columbia. The Forestry Chronicle 85(3):361-371.

Nelson, H., and K. Niquidet. 2009. How do size or tenure influence the competitiveness of BC forestry firms? An evaluation of firm and sector-level effects. Internal report. Economics and Trade Branch, British Columbia Ministry of Forests and Range. Forest Resources Management, University of British Columbia, Vancouver, B.C., Canada.
Parfitt, Ben. 2011. Missing out on green job potential. B.C. forestry industry would profit by increasing value-added exports and ending waste of usable logs. Vancouver Sun newspaper, August 11, 2011, Vancouver, B.C., Canada.

Poyry, J. 2001. Assessment of the status and future opportunities of Ontario's solid wood value-added sector. Living Legacy Trust, Faculty of Natural Resources Management, Lakehead University, Thunder Bay, Ontario, Canada.

R Foundation for Statistical Computing. 2009. R project for statistical computing, version 2.10.1. Institute for Statistics and Mathematics, Wirtschaftsuniversit-Wien, Vienna, Austria. [online] URL: http://cran.r-project.org/bin/windows/ base/old/2.10.1./

Schlüter, M., and C. Pahl-Wostl 2007. Mechanisms of resilience in common-pool resource management systems: an agent-based model of water use in a river basin. Ecology and Society 12(2): 4. [online] URL: http://www.ecologyandsociety. org/vol12/iss2/art4/

Schrier, D. 2003. Value added wood production in BC lagging rest of Canada. Infoline Report 03-34:3-7. BC Stats, British Columbia Ministry of Management Services, Victoria, B.C., Canada.

Stedman, R. C., J. R. Parkins, and N. M. Beckley. 2004. Resource dependence and community well-being in rural Canada. Rural Sociology 69(2):213-234. http://dx.doi. org/10.1526/003601104323087589

Stennes, B., B. Wilson, and S. Wang. 2005. Growth of secondary wood manufacturing in British Columbia, Canada. Forest Products Journal 55(7/8):22-27.

Stennes, B., and B. Wilson. 2008. Secondary manufacturing of solid wood products in British Columbia 2006: structure, economic contributions and changes since 1990. Information Report BC X-416. Pacific Forestry Centre, Natural Resources Canada, Victoria, B.C., Canada.

Tilman, D., J. Knops, D. Wedin, P. Reich, M. Ritchie, and E. Siemann. 1997. The influence of functional diversity and composition on ecosystem processes. Science 277:1300-1302. http://dx.doi.org/10.1126/science.277.5330.1300

Varghese, J., N. T. Krogman, T. M. Beckley, and S. Nadeau. 2006. Critical analysis of the relationship between local ownership and community resiliency. Rural Sociology 71 (3):505-527. http://dx.doi.org/10.1526/003601106778070653

Wilson, B., B. Stennes, S. Wang, and L. Wilson. 2001. Secondary manufacturing in British Columbia: structure, significance, and trends. The Forestry Chronicle 77 (2):301-308. 
Woodbridge, P. 2009. Opportunity BC 2020, BC's forest industry: moving from a volume focus to a value perspective. Business Council of British Columbia, Vancouver, B.C., Canada.

Yaffee, S. 1997. Why environmental policy nightmares recur. Conservation Biology 11(2):328-337. http://dx.doi.org/10.1046/ j.1523-1739.1997.95204.X

Young, N., and R. Matthews. 2007. Resource economies and neoliberal experimentation: the reform of industry and community in rural British Columbia. Area 39(2):176-185. http://dx.doi.org/10.1111/j.1475-4762.2007.00739.x 